\title{
Effect of Packaging Materials and Storage Temperature on Shelf Life Attributes of Ready to Reconstitute Enteral Formula
}

\author{
Premila L. Bordoloi*, Mridula Saikia Barooah, Pranati Das, \\ Moloya Gogoi and Mansi Tiwari
}
Department of Food Science and Nutrition, College of Community Science, Assam Agricultural University, Jorhat - 785013, Assam, India

*Corresponding author

\author{
A B S T R A C T
}

\section{Ke y w o r ds \\ Enteral formula, Balanced, High protein, Packaging materials, Storage temperature}

\section{Article Info}

Accepted:

23 April 2020

Available Online:

10 May 2020
The study aims at investigating shelf life attributes of three developed enteral formulae i.e. Balanced Enteral Formula, High Protein Enteral Formula and High Energy Enteral Formula stored in three different packaging materials (Aluminium foil laminated pouch, polyethylene terephthalate container and airtight glass container) under storage temperature of $27^{\circ} \mathrm{C}$ and $4^{\circ} \mathrm{C}$ for 60 days at an interval of 30 days. The effect of packaging materials and storage temperatures on change in moisture content, free fatty acid content, peroxide value and microbial load of enteral formulae was estimated across storage. A significant $(\mathrm{p}<0.05)$ change in shelf life attributes was observed in all the developed enteral formulae irrespective of the packaging materials and storage temperatures with increased in days of storage. Quality loss was found significantly $(p<0.05)$ higher in enteral formulae stored in polyethylene terephthalate container at $27^{\circ} \mathrm{C}$. Minimal loss of quality across storage was seen in formulae stored in airtight glass container at $4^{\circ} \mathrm{C}$, indicating a better shelf life. Although there was significant change in the product quality, the changes were within the safe limit indicating their acceptability till 60 days of storage.

\section{Introduction}

Optimum nutrition is vital for proper health and well-being of every individual, specifically critically ill patients admitted to intensive care unit (ICU). They are at greater risk of malnutrition which necessitated their requirement for proper nutritional support. Nutritional support is an important therapeutic intervention aims at improving health conditions of critically ill patients. Enteral nutrition therapy (ENT) is provided to patients who are unable to receive at least two third of their daily energy requirement orally (Waitzberg et al., 2004).

ENT covers a wide range of patients suffering from a large spectrum of chronic and acute diseases. Since past 20 years nutrition interventions have substantially evolved from 
merely a supportive strategy to an active therapeutic intervention (Zaloga, 2005). Enteral formulae however are prone to contamination and also an excellent means for growth and multiplication of microorganisms (Scrimshaw, 1991). Further a higher proportion of patients admitted in ICU have altered gastrointestinal function (Mickschl et al., 1990) leading to loss of protection provided by gastrointestinal tract against infection (Broto et al., 1999). Since enteral formulae are designed for at risk group having compromised gut functioning, gut barrier, immune function, protein synthesis, wound healing, liver and renal function (Zaloga, 1999), therefore it is mandatory to ensure aseptic condition during processing and handling of developed formulae. Failure to do so may result several health complications such as infection, diarrhoea, sepsis, pneumonia and colonization of GI tract (Beattie and Anderton, 1998; Anderton, 1993). Therefore the quality of an enteral formula is prime importance to maintain health status of patients and to avoid any health hazards associated to low quality enteral formulae.

Shelf life of a product is an important quality parameter that needs to be considered before commercialization of any food products. It refers to the period commencing from formulation of a food product until it becomes unacceptable either in terms of sensory, nutritional or safety attributes (Kumar et al., 2017). There are several associated factors such as chemical composition of food, processing conditions, packaging materials used and storage conditions that affects shelf life of a product. Exposure of food to several physical and chemical agents like heat, cold, moisture, humidity, air, light, acid and alkali at any stage of product processing and distribution affects the storage stability of a food product (Lotfi et al., 1996). Hence the study was undertaken with the aim to study the shelf life of three different enteral formulations viz., Balanced Enteral Formula, High Protein Enteral Formula and High Energy Enteral Formula developed from natural sources and to evaluate their stability in different packaging material and different storage temperatures.

\section{Materials and Methods}

\section{Sample preparation}

In the present investigation three different ready to reconstitute enteral formulae were formulated. The enteral formulae were composed of malted rice flour, whole green gram malted flour, popped amaranth flour, flaxseed flour, whey powder, milk powder and coconut oil. The preliminary treatments like malting, germination and popping were performed to improve the nutritional and organoleptic qualities of enteral formulae. Rice grains used in formulation of enteral formulae were subjected to steeping, germination, kilning and milling for preparation of malted rice flour. Whole green gram was processed to malted green gram flour as per the method described by Mallashi and Desikachar (1982). White amaranth (Amaranthus curuetus) seeds purchased from marked were popped as per the method outlined by Lara et al., (2007) and flaxseed flour were prepared by cleaning roasting and grinding according to the method of Ganorkar and Jain (2014). These ingredients were mixed thoroughly in definite proportions as presented in Table 1 for formulation of ready to reconstitute enteral formulae in accordance to the recommendation of the ASPEN, ISPEN, ESPEN and criteria adopted by Heimburger and Weinsier (1985).

Hundred gram of each of the three formulated enteral formulae were packed in aluminium foil laminated pouch (AFLP), Polyethylene terephthalate container (PETC) and airtight 
glass container (AGC) under two different temperatures i.e. $27^{\circ} \mathrm{C}$ and $4{ }^{\circ} \mathrm{C}$. Every $30^{\text {th }}$ day, samples were analysed for their change in moisture content, free fatty acid, peroxide value and total plate count across 60 days of storage.

\section{Moisture}

Moisture content of the samples was determined by oven drying method following the procedure of AOAC (2000).

\section{Free fatty acid (FFA)}

Free fatty acid content of samples was determined following the AOAC (1970) method with some modification. The sample of $2 \mathrm{~g}$ was dissolved in $50 \mathrm{~g}$ of neutral solvent in a $250 \mathrm{ml}$ conical flask. Few drops of phenolphthalein indicator $\quad(1 \%$ phenolphthalein in 95\% ethanol) were added to it and the contents were titrated against a $0.10 \mathrm{~N}$ potassium hydroxide solution until a pink colour which persists for 15 seconds was obtained. Titrate value was used for calculation of acid value and free fatty acid as per the given formula:

$$
\text { Acid value }(\mathrm{mg} \mathrm{KOH} / \mathrm{g})=\frac{\text { Titrate value } \times \text { Normality of } \mathrm{KOH} \times 56.1}{\text { Wt of the sample }(\mathrm{g})}
$$

The free fatty acid is calculated as oleic acid using the equation

$$
1 \mathrm{ml} \mathrm{N} / 10 \mathrm{KOH}=0.028 \mathrm{~g} \text { oleic acid }
$$

\section{Peroxide value}

Peroxide value of any food product indicates the extent of fat oxidation due to reaction with oxygen. The estimation of peroxide value was performed using the IS12711 (1989) method. Twenty gram of sample was weighed and transferred to $250 \mathrm{~mL}$ beaker. To the beaker, $100 \mathrm{~mL}$ of chloroform was added and stirred continuously. The content of the beaker was filtered through Whatman No. 1 grade filter paper. Twenty $\mathrm{mL}$ of filtrate was transferred to $100 \mathrm{ml}$ flask, to which $30 \mathrm{~mL}$ glacial acetic acid and $1 \mathrm{~mL}$ saturated iodine solution was added and left undisturbed for 5 minutes.

After 5 minutes, $50 \mathrm{~mL}$ of distilled water was added and the contents were mixed well followed by immediate addition of $1 \mathrm{~mL}$ of 1 per cent starch solution was added and titrated against $0.01 \mathrm{~N}$ sodium thiosulphate solution. The fat content in sample extract was determined by taking $10 \mathrm{~mL}$ of aliquot in an aluminium dish and oven dried at a temperature of $80^{\circ} \mathrm{C}$ until the weight becomes constant. The PV was expressed in milli equivalent of oxygen per $\mathrm{Kg}$ of fat and calculated using the following formula:

$\mathrm{PV}=\frac{(\mathrm{V} 1-\mathrm{V} 2)}{\mathrm{w}} \mathrm{xNx} 1000$

Where, $\mathrm{V}_{1}=$ volume of sodium thiosulphate solution used by sample; $\mathrm{V}_{2}=$ Volume of sodium thiosulphate used by blank $(20 \mathrm{ml}$ chloroform was used as blank); $\mathrm{N}=$ Normality of sodium thiosulphate solution used; W= weight of fat content in $20 \mathrm{~mL}$ of aliquot

\section{Microbiological assay}

The microbial load of the developed enteral formulae in terms of the Total Plate Count (TPC) was determined by employing pour plate technique described by ICMSF (1988). In a test tube containing $9 \mathrm{ml}$ of sterile water, $1 \mathrm{~g}$ sample was weighed into it and agitated thoroughly in a vortex for 1-2minutes. Serial dilution was done up to $10^{-3}$ concentration followed by aseptically inoculating $1 \mathrm{ml}$ of aliquot of serial dilution of $10^{-3}$ concentration on a petri dish containing Potato Dextrose Agar. The inoculated plates were placed inverted in an incubator and microbial growth was recorded at regular intervals. 


\section{Statistical analysis}

Statistical analysis were performed using Microsoft office excel 2007 and Statistical Package for Social Science version 20.0 software. The effect of temperature and packaging materials on the shelf life attributes of developed enteral formulae across storage were determined by employing one way analysis of variance followed by post hoc analysis using Duncan test. Pearson correlation was performed to test the correlation between shelf life attributes of the developed enteral formulae.

\section{Results and Discussion}

\section{Change in moisture content of enteral formulae across storage}

Studies have found the moisture content of a product to be a major determinant of the storage stability of the product. Moisture levels of the developed enteral formulae were monitored at regular interval across storage period. The change in moisture content of the three ready to reconstitute enteral formulae is presented in Table 2. The moisture content of all the developed enteral formulae increased across storage irrespective of packaging materials used and storage temperature. This change could be attributed to storage temperature, packaging used, interaction between storage and packaging and hygroscopic properties of flour (Krik and Sawyer, 1991; Rehman and Shah, 1999). The moisture content of the BEF packed in AFLP increased significantly $(\mathrm{p}<0.05)$ from 5.43 $\mathrm{g} / 100 \mathrm{~g}$ to $6.73 \mathrm{~g} / 100 \mathrm{~g}$, in case of PETC to $6.99 \mathrm{~g} / 100 \mathrm{~g}$ and to $6.71 \mathrm{~g} / 100 \mathrm{~g}$ in BEF packed in AGC at $27^{\circ} \mathrm{C}$ storage temperature. However the moisture content of BEF stored at $4^{\circ} \mathrm{C}$ did not varied significantly across storage. Similar trends of increased moisture were observed for HPEF and HEEF although not significant $(p>0.05)$. From the Table 2 it is evident that highest increase in moisture was observed in enteral formulae stored in PETC while the lowest change was observed in formulae stored in AGC which might be due to variation in water vapour transmission rate of the packaging materials used. However the change in moisture content of all the developed enteral formulae was within the standard acceptable limit below 9.00 per cent as per IS7836 Indian Standards (AgrahaMurugkar and Jha, 2011).

\section{Change in FFA content of enteral formulae across storage}

Lipid content of a product may contribute to loss of sensory quality across storage. Chemical or enzymatic hydrolysis of triglycerides produce a mixture of diacyl glycerol molecules, monoacyl glycerol molecules, free fatty acids and glycerol molecules (Frankel, 2005). Several factors such as availability of oxygen, moisture, temperature as well as packaging materials used greatly controls the rate at which this reaction occurs (Manzocco and Lagazio, 2009; Speer and Kolling, 2006). The oxidation of FFA is responsible for the formation of a large number of volatile compounds which results loss of positive attributes such as freshness (Frankel, 2005).The effect of storage temperature and packaging materials on FFA contents are showcased in Table 3. Table illustrates that the FFA content of developed enteral formulae increased significantly $(\mathrm{p}<0.05)$ across storage. The FFA content of BEF stored in AGC increased from 0.71 to 1.70 $\mathrm{mg} / 100 \mathrm{~g}$ at $27^{\circ} \mathrm{C}$ which was lower than BEF packed in PETC $(1.91 \mathrm{mg} / 100 \mathrm{~g})$ and AFLP $(1.80 \mathrm{mg} / 100 \mathrm{~g})$ after 60 days. In case of HPEF and HEEF, the FFA content in the initial day was $0.32 \mathrm{mg} / 100 \mathrm{~g}$ and 0.78 $\mathrm{mg} / 100 \mathrm{~g}$ which increased significantly $(\mathrm{p}<0.05)$ to 0.79 and $1.31 \mathrm{mg} / 100 \mathrm{~g}, 0.82$ and $1.42 \mathrm{mg} / 100 \mathrm{~g}, \quad 0.84$ and $1.41 \mathrm{mg} / 100 \mathrm{~g}$ 
respectively on storage in AFLP, PETC and AGC at $27^{\circ} \mathrm{C}$. However, storage at $4^{\circ} \mathrm{C}$ displayed a lower range of FFA in all the enteral formulae stored in different packaging materials. As far as the packaging materials are concerned the FFA content was more prominent in PETC and AFLP compared to lower change in FA of formulae stored in AGC which could be correlated to the rise in moisture in respective packaging materials. The discrepancy in the FFA content of various enteral formulae could be due to difference in the ingredients used for formulation of formula mixes. Increase in total amount of FFA during storage might be attributed to the activities of lipases and lipolytic acyl-hydrolases (Molteberg et al., 2014).

\section{Change in peroxide value of enteral formulae across storage}

Peroxide value of food product is a principle method determining the shelf life quality. It is a quantitative indicator of degree of rancidity of food products. The change in peroxide value of developed enteral formulae across storage for a period of 60 days stored in different packaging material under different storage temperatures is presented in Table 4. The peroxide value of BEF stored in AFLP, PETC and AGC stored at $27{ }^{\circ} \mathrm{C}$ increased significantly $(\mathrm{p}<0.05)$ from $0.13 \mathrm{mEq} \mathrm{O} / \mathrm{kg}$ fat to $3.11,3.06$ and $2.02 \mathrm{mEq} \mathrm{O} / \mathrm{kg}$ fat respectively while that stored at $0^{\circ} \mathrm{C}$ increased significantly to $1.13,1.28$ and $1.05 \mathrm{mEq}$ $\mathrm{O}_{2} / \mathrm{kg}$ fat respectively. Although increment was observed both under $27^{\circ} \mathrm{C}$ and $4^{\circ} \mathrm{C}$ but the range of increment was lower at $4^{\circ} \mathrm{C}$ indicating better quality. The increase in peroxide values during storage is probably due to peroxidation of double bonds in unsaturated fatty acids which respectively break down in order to produce secondary oxidation products that may indicate rancidity (Gahlawat and Sehgal, 1994).
As far as the packaging materials are concerned the least change in peroxide value was in AGC at both the temperatures. Similar trends of change in peroxide value were seen in case of HPEF and HEEF across storage. Although the PV of all the developed formulae increased significantly but were much lower than the acceptable limit of peroxide value $\left(<10 \quad 10 \mathrm{mEqO}_{2} / \mathrm{kg}\right.$ fat $)$ as suggested by Aylward (1999). Vidhyasagar et al., (1991) studied the effect of oil seed incorporation on the storage stability of developed instant cereal mix.

The study showed a much higher formation of peroxide in contrast to that observed in the present investigation. Similarly, the findings of Rao (2000) for modak (4.8 $\mathrm{mEqO}_{2} / \mathrm{kg}$ fat) and Prakash et al., (1991) for khakra $\left(3.7 \mathrm{mEqO}_{2} / \mathrm{kg}\right.$ fat) have shown conformity with the present investigation. The work done by Lohia and Udipi (2015) also reported a higher peroxide value of $5.12 \mathrm{mEq} \mathrm{O} / \mathrm{kg}$ fat which increased to $9.94 \mathrm{mEq} \mathrm{O} / \mathrm{kg}$ fat after 14 days of storage. This short shelf life may be due to storage in polyethylene bags at room temperature.

\section{Change in microbial load of enteral formulae across storage}

The microbial safety of an enteral formula is the most important attribute rendering product saety. The microbial quality of the developed enteral formulae in terms of total plate count (TPC) is presented in Table 5. A significant increase in TPC of all the developed enteral formulae was seen irrespective of the packaging materials used and storage temperatures. The TPC of the BEF stored at $27^{\circ} \mathrm{C}$ showed greater increase in the TPC across storage of 60 days. Among the packaging materials used the BEF stored in PETC showed a greater rise compared to other packaging materials. Similar trend was in the case of HPEF and HEEF. 
Table.1 Proportion of ingredients used for formulation of enteral formulae

\begin{tabular}{|c|c|c|c|c|c|c|c|}
\hline & \multicolumn{7}{|c|}{ Ingredients } \\
\hline $\begin{array}{c}\text { Enteral } \\
\text { formulae }\end{array}$ & $\begin{array}{c}\text { Malted } \\
\text { rice } \\
\text { flour } \\
\text { (g) }\end{array}$ & $\begin{array}{c}\text { Malted } \\
\text { green gram } \\
\text { flour } \\
\text { (g) }\end{array}$ & $\begin{array}{c}\text { Popped } \\
\text { amaranth } \\
\text { flour }\end{array}$ & $\begin{array}{c}\text { Flaxseed } \\
\text { flour } \\
(\mathbf{g})\end{array}$ & $\begin{array}{c}\text { Skimmed } \\
\text { milk } \\
\text { powder } \\
(\mathbf{g})\end{array}$ & $\begin{array}{c}\text { Whey } \\
\text { protein } \\
\text { powder } \\
(\mathbf{g})\end{array}$ & $\begin{array}{c}\text { Coconut } \\
\text { oil } \\
(\mathbf{m l})\end{array}$ \\
\hline BEF & 40 & 25 & 15 & 5 & 5 & ---- & 10 \\
\hline HPEF & 20 & 30 & 20 & 5 & 10 & 10 & 5 \\
\hline HEEF & 40 & 20 & 10 & 10 & 5 & 10 & 5 \\
\hline
\end{tabular}

$\mathrm{BEF}=$ Balanced Enteral Formula; HPEF= High Protein Enteral Formula; HEEF= High Energy Enteral Formula

Table.2 Effect of packaging materials and storage temperature on moisture content $(\mathrm{g} / 100 \mathrm{~g})$ of developed Enteral Formulae across storage

\begin{tabular}{|c|c|c|c|c|c|c|c|}
\hline \multirow[t]{2}{*}{ Formula } & \multirow{2}{*}{$\begin{array}{c}\text { Storage } \\
\text { days }\end{array}$} & \multicolumn{3}{|c|}{$27^{\circ} \mathrm{C}$} & \multicolumn{3}{|c|}{$4^{\circ} \mathrm{C}$} \\
\hline & & AFLP & PETC & AGC & AFLP & PETC & AGC \\
\hline \multirow[t]{3}{*}{ BEF } & 0 & $5.43 \pm 0.27^{\mathrm{a}}$ & $5.43 \pm 0.27^{\mathrm{a}}$ & $5.43 \pm 0.27^{\mathrm{a}}$ & $5.43 \pm 0.27^{\mathrm{a}}$ & $5.43 \pm 0.27^{\mathrm{a}}$ & $5.43 \pm 0.27^{\mathrm{a}}$ \\
\hline & 30 & $6.05 \pm 0.32^{b}$ & $6.23 \pm 0.54^{b}$ & $6.03 \pm 0.15^{b}$ & $5.49 \pm 0.16^{\mathrm{a}}$ & $5.52 \pm 0.29^{\mathrm{a}}$ & $5.47 \pm 0.31^{\mathrm{a}}$ \\
\hline & 60 & $6.73 \pm 0.16^{c}$ & $6.99 \pm 9.23^{c}$ & $6.71 \pm 0.34^{c}$ & $5.53 \pm 0.45^{\mathrm{a}}$ & $5.68 \pm 0.34^{\mathrm{a}}$ & $5.55 \pm 0.27^{\mathrm{a}}$ \\
\hline \multirow[t]{3}{*}{ HPEF } & 0 & $5.64 \pm 0.54^{\mathrm{a}}$ & $5.64 \pm 0.54^{\mathrm{a}}$ & $5.64 \pm 0.54^{\mathrm{a}}$ & $5.64 \pm 0.54^{\mathrm{a}}$ & $5.64 \pm 0.54^{\mathrm{a}}$ & $5.64 \pm 0.54^{\mathrm{a}}$ \\
\hline & 30 & $5.78 \pm 0.52^{\mathrm{a}}$ & $5.77 \pm 0.63^{\mathrm{a}}$ & $5.73 \pm 0.42^{a}$ & $5.69 \pm 0.46^{\mathrm{a}}$ & $5.72 \pm 0.85^{\mathrm{a}}$ & $5.72 \pm 0.36^{\mathrm{a}}$ \\
\hline & 60 & $6.07 \pm 0.86^{\mathrm{a}}$ & $6.11 \pm 0.27^{a}$ & $5.98 \pm 0.23^{a}$ & $5.84 \pm 0.40^{\mathrm{a}}$ & $6.05 \pm 0.74^{\mathrm{a}}$ & $5.93 \pm 0.75^{\mathrm{a}}$ \\
\hline \multirow[t]{3}{*}{ HEEF } & 0 & $5.66 \pm 0.64^{\mathrm{a}}$ & $5.66 \pm 0.64^{\mathrm{a}}$ & $5.66 \pm 0.64^{\mathrm{a}}$ & $5.66 \pm 0.64^{\mathrm{a}}$ & $5.66 \pm 0.64^{\mathrm{a}}$ & $5.66 \pm 0.64^{a}$ \\
\hline & 30 & $6.12 \pm 1.02^{\mathrm{a}}$ & $6.07 \pm 0.45^{\mathrm{a}}$ & $5.99 \pm 0.72^{a}$ & $5.69 \pm 0.74^{\mathrm{a}}$ & $5.78 \pm 0.37^{\mathrm{a}}$ & $5.70 \pm 0.64^{\mathrm{a}}$ \\
\hline & 60 & $6.33 \pm 0.61^{\mathrm{a}}$ & $6.69 \pm 0.37^{\mathrm{a}}$ & $6.15 \pm 0.48^{\mathrm{a}}$ & $5.79 \pm 0.47^{\mathrm{a}}$ & $5.83 \pm 0.28^{\mathrm{a}}$ & $5.74 \pm 0.57^{\mathrm{a}}$ \\
\hline
\end{tabular}

Note. Values are mean \pm Standard deviation of triplicates. Values with different superscript in same column for the attribute differs significantly $(\mathrm{p}<0.05)$

AFLP= Aluminium Foil Laminated Pouch; PEPC=Polyethylene terephthalate container; AGC $=$ Glass container $\mathrm{BEF}=$ Balanced Enteral Formula; HPEF= High Protein Enteral Formula; HEEF= High Energy Enteral Formula

Table.3 Effect of packaging materials and storage temperature on free fatty acid content of developed $(\mathrm{mg} / 100 \mathrm{~g})$ enteral formulae across storage

\begin{tabular}{|c|c|c|c|c|c|c|c|}
\hline \multirow[t]{2}{*}{ Formula } & \multirow{2}{*}{$\begin{array}{c}\text { Storage } \\
\text { days }\end{array}$} & \multicolumn{3}{|c|}{$27^{\circ} \mathrm{C}$} & \multicolumn{3}{|c|}{$4^{\circ} \mathrm{C}$} \\
\hline & & AFLP & PETC & AGC & AFLP & PETC & AGC \\
\hline \multirow[t]{3}{*}{ BEF } & 0 & $0.71 \pm 0.02^{\mathrm{a}}$ & $0.71 \pm .02^{\mathrm{a}}$ & $0.71 \pm 0.02^{\mathrm{a}}$ & $0.71 \pm 0.02^{\mathrm{a}}$ & $0.71 \pm 0.02^{\mathrm{a}}$ & $0.71 \pm 0.02^{\mathrm{a}}$ \\
\hline & 30 & $1.50 \pm 0.03^{b}$ & $1.48 \pm 0.02^{b}$ & $1.21 \pm 0.02^{b}$ & $0.79 \pm 0.01^{b}$ & $0.77 \pm 0.01^{b}$ & $0.79 \pm 0.02^{b}$ \\
\hline & 60 & $1.80 \pm 0.04^{\mathrm{c}}$ & $1.91 \pm 0.02^{c}$ & $1.70 \pm 0.03^{c}$ & $0.83 \pm 0.02^{\mathrm{c}}$ & $0.89 \pm 0.01^{\mathrm{c}}$ & $0.82 \pm 0.01^{b}$ \\
\hline \multirow[t]{3}{*}{ HPEF } & 0 & $0.32 \pm 0.02^{\mathrm{a}}$ & $0.32 \pm 0.02^{\mathrm{a}}$ & $0.32 \pm 0.02^{\mathrm{a}}$ & $0.32 \pm 0.02^{\mathrm{a}}$ & $0.32 \pm 0.02^{\mathrm{a}}$ & $0.32 \pm 0.02^{\mathrm{a}}$ \\
\hline & 30 & $0.52 \pm 0.03^{b}$ & $0.61 \pm 0.01^{b}$ & $0.70 \pm 0.02^{b}$ & $0.39 \pm 0.01^{b}$ & $0.4 \pm 0.01^{b}$ & $0.39 \pm 0.02^{b}$ \\
\hline & 60 & $0.79 \pm 0.02^{c}$ & $0.82 \pm 0.04^{c}$ & $0.84 \pm 0.03^{c}$ & $0.40 \pm 0.01^{\mathrm{b}}$ & $0.51 \pm 0.02^{c}$ & $0.41 \pm 0.01^{b}$ \\
\hline \multirow[t]{3}{*}{ HEEF } & 0 & $0.78 \pm 0.01^{\mathrm{a}}$ & $0.78 \pm 0.01^{\mathrm{a}}$ & $0.78 \pm 0.01^{\mathrm{a}}$ & $0.78 \pm 0.01^{\mathrm{a}}$ & $0.78 \pm 0.01^{\mathrm{a}}$ & $0.78 \pm 0.01^{\mathrm{a}}$ \\
\hline & 30 & $1.01 \pm 0.0$ & $1.60 \pm 0.03^{b}$ & $1.20 \pm 0 .($ & $0.79 \pm 0.02^{\mathrm{a}}$ & $0.82 \pm 0.02^{b}$ & $0.80 \pm 0.01^{b}$ \\
\hline & 60 & $1.31 \pm 0.02^{\mathrm{c}}$ & $1.42 \pm 0.02^{\mathrm{c}}$ & $1.41 \pm 0.03^{c}$ & $0.82 \pm 0.01^{b}$ & $0.83 \pm 0.02^{b}$ & $0.80 \pm 0.01^{\mathrm{b}}$ \\
\hline
\end{tabular}

Note. Values are mean \pm Standard deviation of triplicates. Values with different superscript in same column for the attribute differs significantly $(\mathrm{p}<0.05)$

AFLP= Aluminium Foil Laminated Pouch; PEPC=Polyethylene terephthalate container; AGC $=$ Glass container $\mathrm{BEF}=$ Balanced Enteral Formula; HPEF= High Protein Enteral Formula; HEEF= High Energy Enteral Formula 
Table.4 Effect of packaging materials and storage temperature on peroxide value $\left(\mathrm{mEq} \mathrm{O}_{2} / \mathrm{kg}\right.$ fat) of developed Enteral Formulae across storage

\begin{tabular}{|l|c|c|c|c|c|c|c|}
\hline Formula & $\begin{array}{c}\text { Storage } \\
\text { days }\end{array}$ & \multicolumn{3}{|c|}{$\mathbf{2 7}^{\circ} \mathbf{C}$} & \multicolumn{3}{|c|}{$\mathbf{4}^{\circ} \mathbf{C}$} \\
\cline { 2 - 8 } & & AFLP & PETC & AGC & AFLP & PETC & AGC \\
\hline BEF & 0 & $0.13 \pm 0.01^{\mathrm{a}}$ & $0.13 \pm 0.01^{\mathrm{a}}$ & $0.13 \pm 0.01^{\mathrm{a}}$ & $0.13 \pm 0.01^{\mathrm{a}}$ & $0.13 \pm 0.01^{\mathrm{a}}$ & $0.13 \pm 0.01^{\mathrm{a}}$ \\
& 30 & $1.73 \pm 0.02^{\mathrm{b}}$ & $1.92 \pm 0.00^{\mathrm{b}}$ & $1.38 \pm 0.05^{\mathrm{b}}$ & $0.49 \pm 0.03^{\mathrm{b}}$ & $0.37 \pm 0.01^{\mathrm{b}}$ & $0.21 \pm 0.00^{\mathrm{b}}$ \\
& 60 & $3.11 \pm 0.02^{\mathrm{c}}$ & $3.06 \pm 0.02^{\mathrm{c}}$ & $2.02 \pm 0.04^{\mathrm{c}}$ & $1.13 \pm 0.11^{\mathrm{c}}$ & $1.28 \pm 0.10^{\mathrm{c}}$ & $.05 \pm 0.03^{\mathrm{c}}$ \\
\hline \multirow{2}{*}{ HPEF } & 0 & $0.43 \pm 0.02^{\mathrm{a}}$ & $0.43 \pm 0.02^{\mathrm{a}}$ & $0.43 \pm 0.02^{\mathrm{a}}$ & $0.43 \pm 0.02^{\mathrm{a}}$ & $0.43 \pm 0.02^{\mathrm{a}}$ & $0.43 \pm 0.02^{\mathrm{a}}$ \\
\hline & 30 & $1.52 \pm 0.05^{\mathrm{b}}$ & $1.80 \pm 0.04^{\mathrm{b}}$ & $2.38 \pm 0.04^{\mathrm{b}}$ & $0.59 \pm 0.05^{\mathrm{b}}$ & $0.99 \pm 0.03^{\mathrm{b}}$ & $0.76 \pm 0.00^{\mathrm{b}}$ \\
\hline \multirow{2}{*}{ HEEF } & 60 & $3.42 \pm 0.04^{\mathrm{c}}$ & $3.10 \pm 0.02^{\mathrm{c}}$ & $3.46 \pm 0.02^{\mathrm{c}}$ & $1.15 \pm 0.03^{\mathrm{c}}$ & $1.41 \pm 0.11^{\mathrm{c}}$ & $1.28 \pm 0.03^{\mathrm{c}}$ \\
& 0 & $0.35 \pm 0.01^{\mathrm{a}}$ & $0.35 \pm 0.01^{\mathrm{a}}$ & $0.35 \pm 0.01^{\mathrm{a}}$ & $0.35 \pm 0.01^{\mathrm{a}}$ & $0.35 \pm 0.01^{\mathrm{a}}$ & $0.35 \pm 0.01^{\mathrm{a}}$ \\
& 30 & $2.41 \pm 0.05^{\mathrm{b}}$ & $2.08 \pm 0.14^{\mathrm{b}}$ & $2.38 \pm 0.05^{\mathrm{b}}$ & $0.87 \pm 0.03^{\mathrm{b}}$ & $1.00 \pm 0.02^{\mathrm{b}}$ & $1.01 \pm 0.06^{\mathrm{b}}$ \\
& 60 & $3.52 \pm 0.04^{\mathrm{c}}$ & $3.96 \pm 0.02^{\mathrm{c}}$ & $5.46 \pm 0.02^{\mathrm{c}}$ & $1.45 \pm 0.03^{\mathrm{c}}$ & $1.38 \pm 0.10^{\mathrm{c}}$ & $1.17 \pm 0.11^{\mathrm{c}}$ \\
\hline
\end{tabular}

Note. Values are mean \pm Standard deviation of triplicates. Values with different superscript in same column for the attribute differs significantly $(\mathrm{p}<0.05)$

AFLP $=$ Aluminium Foil Laminated Pouch; PEPC=Polyethylene terephthalate container; $A G C=$ Glass container $\mathrm{BEF}=$ Balanced Enteral Formula; HPEF= High Protein Enteral Formula; HEEF= High Energy Enteral Formula

Table.5 Effect of packaging materials and storage temperature on total plate count $\left(10^{3} \mathrm{cfug}^{-1}\right)$ of developed Enteral Formulae across storage

\begin{tabular}{|c|c|c|c|c|c|c|c|}
\hline \multirow[t]{2}{*}{ Formula } & \multirow{2}{*}{$\begin{array}{c}\text { Storage } \\
\text { days }\end{array}$} & \multicolumn{3}{|c|}{$27^{\circ} \mathrm{C}$} & \multicolumn{3}{|c|}{$4^{\circ} \mathrm{C}$} \\
\hline & & AFLP & PETC & AGC & AFLP & PETC & AGC \\
\hline \multirow[t]{3}{*}{ BEF } & 0 & $5.33 \pm 0.31^{\mathrm{a}}$ & $5.33 \pm 0.31^{\mathrm{a}}$ & $5.33 \pm 0.31^{\mathrm{a}}$ & $5.33 \pm 0.31^{\mathrm{a}}$ & $5.33 \pm 0.31^{\mathrm{a}}$ & $5.33 \pm 0.31^{\mathrm{a}}$ \\
\hline & 30 & $6.33 \pm 0.53^{\mathrm{a}}$ & $7.87 \pm 0.74^{b}$ & $6.33 \pm 0.59^{\mathrm{a}}$ & $6.53 \pm 0.63^{b}$ & $6.33 \pm 0.58^{b}$ & $5.99 \pm 0.85^{\mathrm{a}}$ \\
\hline & 60 & $10.99 \pm 0.74^{b}$ & $9.67 \pm 0.79^{c}$ & $10.99 \pm 1.27^{b}$ & $7.69 \pm 0.42^{\mathrm{c}}$ & $8.99 \pm 0.37^{\mathrm{c}}$ & $7.69 \pm 0.74^{b}$ \\
\hline \multirow[t]{3}{*}{ HPEF } & 0 & $3.33 \pm 0.25^{\mathrm{a}}$ & $3.33 \pm 0.25^{\mathrm{a}}$ & $3.33 \pm 0.25^{\mathrm{a}}$ & $3.33 \pm 0.25^{\mathrm{a}}$ & $3.33 \pm 0.25^{\mathrm{a}}$ & $3.33 \pm 0.25^{\mathrm{a}}$ \\
\hline & 30 & $6.12 \pm 0.43^{b}$ & $5.98 \pm 0.23^{b}$ & $5.99 \pm 0.30^{b}$ & $4.33 \pm 0.84^{\mathrm{a}}$ & $4.78 \pm 0.14^{b}$ & $3.67 \pm 0.38^{\mathrm{a}}$ \\
\hline & 60 & $8.99 \pm 0.36^{c}$ & $8.69 \pm 0.49^{c}$ & $7.87 \pm 0.48^{c}$ & $6.67 \pm 0.94^{b}$ & $6.33 \pm 0.73^{c}$ & $6.33 \pm 0.89^{b}$ \\
\hline \multirow[t]{3}{*}{ HEEF } & 0 & $5.99 \pm 0.71^{\mathrm{a}}$ & $5.99 \pm 0.71^{\mathrm{a}}$ & $5.99 \pm 0.71^{\mathrm{a}}$ & $5.99 \pm 0.71^{\mathrm{a}}$ & $5.99 \pm 0.71^{\mathrm{a}}$ & $5.99 \pm 0.71^{\mathrm{a}}$ \\
\hline & 30 & $10.99 \pm 1.02^{\mathrm{b}}$ & $10.99 \pm 0.50^{b}$ & $8.99 \pm 0.38^{\mathrm{b}}$ & $7.00 \pm 0.78^{\mathrm{a}}$ & $7.33 \pm 0.68^{\mathrm{a}}$ & $7.00 \pm 0.36^{\mathrm{a}, \mathrm{b}}$ \\
\hline & 60 & $17.00 \pm 0.96^{\mathrm{c}}$ & $17.33 \pm 0.69^{c}$ & $12.00 \pm 0.83^{\mathrm{c}}$ & $8.99 \pm 0.95^{\mathrm{b}}$ & $10.67 \pm 0.83^{\mathrm{b}}$ & $7.87 \pm 0.47^{b}$ \\
\hline
\end{tabular}

Note. Values are mean \pm Standard deviation of triplicates. Values with different superscript in same column for the attribute differs significantly $(\mathrm{p}<0.05)$

AFLP= Aluminium Foil Laminated Pouch; PEPC=Polyethylene terephthalate container; AGC= Glass container $\mathrm{BEF}=$ Balanced Enteral Formula; HPEF= High Protein Enteral Formula; HEEF= High Energy Enteral Formula 
Table.6 Pearson's correlation coefficient between shelf life attributes of developed Balanced Enteral Formula (BEF)

\begin{tabular}{|c|c|c|c|c|}
\hline & Moisture & FFA & PV & TPC \\
\hline Moisture & 1.000 & 0.984 & 0.944 & 0.831 \\
\hline FFA & 0.984 & 1.000 & 0.950 & 0.788 \\
\hline PV & 0.944 & 0.950 & 1.000 & 0.872 \\
\hline TPC & 0.831 & 0.788 & 0.872 & 1.000 \\
\hline
\end{tabular}

FFA= Free Fatty Acid; PV= Peroxide Value; TPC $=$ Total Plate Count The correlation is significant at $1 \%$ level of significance

Table.7 Pearson's correlation coefficient between shelf life attributes of developed High Protein Enteral Formula

\begin{tabular}{|c|c|c|c|c|}
\hline & Moisture & FFA & PV & TPC \\
\hline Moisture & 1.000 & 0.755 & 0.813 & 0.921 \\
\hline FFA & 0.755 & 1.000 & 0.971 & 0.871 \\
\hline PV & 0.813 & 0.971 & 1.000 & 0.925 \\
\hline TPC & 0.921 & 0.871 & 0.925 & 1.000 \\
\hline
\end{tabular}

FFA= Free Fatty Acid; PV= Peroxide Value; TPC $=$ Total Plate Count The correlation is significant at $1 \%$ level of significance

Table.8 Pearson's correlation coefficient between shelf life attributes of developed High Energy Enteral Formula

\begin{tabular}{|c|c|c|c|c|}
\hline & Moisture & FFA & PV & TPC \\
\hline Moisture & 1.000 & 0.842 & 0.860 & 0.956 \\
\hline FFA & 0.842 & 1.000 & 0.831 & 0.786 \\
\hline PV & 0.860 & 0.831 & 1.000 & 0.843 \\
\hline TPC & 0.956 & 0.786 & 0.843 & 1.000 \\
\hline
\end{tabular}

FFA= Free Fatty Acid; PV= Peroxide Value; TPC= Total Plate Count

The correlation is significant at $1 \%$ level of significance

The recorded values were found within the reported maximum permissible level of the TPC as per the FSSAI (2011). In many studies data of microbial content of developed enteral formulas were reported at the level of $10^{3} \mathrm{cfug}^{-1}$ (Anderton, 1990) which is in conformity to the present study.

\section{Pearson's correlation coefficients between the shelf life attributes of developed enteral formulae}

The correlation among all the shelf life attributes of the developed enteral formulae i.e. BEF, HPEF and HEEF are given in Table 6,7 and 8 respectively. Table 6 elucidates that there is a strong positive correlation of moisture content of the developed BEF to FFA $(r=0.984), \quad P V \quad(r=0.944)$ and TPC $(\mathrm{r}=0.831)$. The table also showed a strong significant correlation $(\mathrm{p}<0.01)$ of FFA to PV $(\mathrm{r}=0.950)$ and TPC $(\mathrm{r}=0.788)$ of the developed BEF.

The correlation coefficient between shelf life attributes of HPEF as displayed in table 7 
showed a strong significant correlation between attributes. A comparatively stronger correlation between moisture content and TPC with $r$ value of 0.921 was observed Compared to BEF. Similar to BEF and HPEF, the developed HEEF also showed significantly strong $(\mathrm{p}<0.01) \quad$ correlation between shelf life attributes.

It is evident from the investigation that there is significant effect of packaging materials and storage temperature on the shelf life attributes of developed ready to reconstitute enteral formulae across storage. Minimal quality loss was recorded at product stored at $4^{\circ} \mathrm{C}$ as compared to the product stored at $27^{\circ} \mathrm{C}$. Among the different packaging materials used during storage, the airtight glass container had better barrier properties owing to minimal quality losses in all the formulae across the storage.

\section{References}

A.O.A.C. 1970. Official method of analysis XI Edn. Association of Official Analytical Chemists, Washington D. C.

A.O.A.C. 2000. Official methods of Analysis XVII Edn. Association of Official Analytical Chemist. Gaithersburg, MD, USA.

Agrahar-Murugkar, D., and Jha, K. 2011. Influence of storage and packaging condition on the quality of soy flour from sprouted soybean. J. Food Sci. Technol.12: 205-212.

Anderton, A. 1990. Microbial aspects of home enteral nutrition-a discussion. . J Hum. Nutr. Diet. 3(6): 403-412.

Anderton, A. 1993. Bacterial contamination of enteral feeds and feeding systems. Clin. Nutr. 12: S16-S32.

Aylward, F. 1999. Food technology, processing and laboratory control. Allied Science Publishers, India, pp. 179-181.
Beattie, T., and Anderton, A. 1998. Bacterial contamination of enteral feeding systems due to faulty handling procedures-a comparison of a new system with two established systems. J Hum. Nutr. Diet. 11(4): 313-321.

Broto, M.P.L., Adjunto, L.F., and Garrido, V.R. 1999. Contamination de nutricionesenterales pacientescriticos. Nutr. Hosp. 9: 18-26.

Frankel, E.N. 2005. Lipid Oxidation, $2^{\text {nd }}$ edn, Woodhead Publishing Ltd., Sawston, Cambridge, UK.

Gahwalt, P., and Sehgal, S. 1994. Shelf life of weaning foods developed from locally available food stuff. Plant Foods Hum. Nutr. 45(4): 349-355.

Ganorkar, P., and Jain, R. 2014. Effect of flaxseed incorporation on physical, sensorial , textural and chemical attributes of cookies. Ins. Food Res. J. $: 1515-1521$

Heimburger, D.C., and Weinsier R.L. 1985. Guidelines for evaluating and categorizing enteral feeding formulas according to the therapeutic equivalence. J Parenter Enteral Nutr. 9(1): 61-67

ICMSF. 1988. Microorganisms in Foods 4: Application of Hazard Analysis and Critical Control point Systems to ensure Microbiological Safety and Quality. Black well Scientific Publications, UK.

IS12711. 1989. Bakery products-methods of analysis. Bureau of Indian standards, New Delhi

Kirk, R.S., and Sawyer, R. 1991. Pearson's Composition and Analysis of Foods, $9^{\text {th }}$ ed. (student edition), England : Addision Wesley Longman Ltd., pp. 33-36.

Kumar, C.M., Raju, P. N., and Singh, A. K. 2017. Effect of packaging materials and storage temperatures on shelf life of micronutrient fortified milk-cereal based complementary food. J Packag. Technol. Res. 1(3): 135-148. 
Lohia, N., and Udipi, S.A. 2015. Use of fermentation and malting for development of ready-to-use complementary food mixes. Int. J Food Nutr. Sci. 4(1): 77.

Lotfi, M., Mannar, M.G.V., Merx, R..HJ.M., Naber-Van, D., and Heuvel, P. 1996. Micronutrient fortifcation of foods: current practices, research and opportunities, ottawa: the micronutrient initiative. International Agriculture Centre, Wageningen.

Malleshi, N. G., and Deshikachar, H.S.R. 1982. Formulation of weaning food with low hot paste viscosity based on malted Ragi and green gram. J Food Sci. Technol. 19: 193-197

Manzocco, L., and Lagazio, C. 2009. Coffee brew shelf life modelling by integration of acceptability and quality data. Food Qual. Prefer.20: 24-29.

Mickschl, D.B., Davidson, L.J., Flournoy, D.J., and Paker, D.E. 1990. Contamination of enteral feedings and diarrhoea in patients in intensive care units. Heart Lung. 19:362-370.

Molteberg, E.L., Vogt, G., Nilsson, A., and Frolich, W. 2014. Effects of Storage and Heat Processing on the Content and Composition of Free Fatty Acids in Oats. Cereal Chem. 72(1): 88-93.

Prakash, M., Dastur, K.S. and Bhattacharya,
S. 1991. Studies on the storage characteristics of Khakra. J Food Sci. Technol. 33(5): 407-409.

Rao, P. 2000. Traditional foods. Nutrition. Nat. Inst. Nutr. 34: 11-20.

Rehman, Z.U., and Shah, W.H. 1999. Biochemical changes in wheat during storage at three temperatures. Plant Food Human Nutr. 54(2): 109-117.

Scrimshaw, N. S. 1991. Rhoads lecture. Effect of infection on nutrient requirements. Journal of Parenteral and Enteral Nutrition, 15(6), 589-600.

Speer, K. and Kolling, S.I. 2006. The lipid fraction of the coffee bean. Braz. J. Plant Physiol.18: 201-216.

Vidhyasagar, K., Premavaili, K.S., and Arya, S.S. 1991. Effect of oils and packaging materials on the storage stability of instant cereal mix. Indian Food Packer. 45(1): 24-27.

Waitzberg, D. L., and Campos, A. C. 2004. Nutrition support in Brazil: past, present, and future perspectives. J Parenter. Enter. Nutr. 28(3): 184-191.

Zaloga G.P. 2005. Improving outcomes with specialized nutrition support. J Parenter. Enter. Nutr. 29(1): S49-S51.

Zaloga, G.P. 1999. Early enteral nutritional support improves outcome: hypothesis or fact? Crit. Care Med. 27(2): 259-261.

\section{How to cite this article:}

Premila L. Bordoloi, Mridula Saikia Barooah, Pranati Das, Moloya Gogoi and Mansi Tiwari. 2020. Effect of Packaging Materials and Storage Temperature on Shelf Life Attributes of Ready to Reconstitute Enteral Formula. Int.J.Curr.Microbiol.App.Sci. 9(05): 2980-2989. doi: https://doi.org/10.20546/ijcmas.2020.905.341 